\title{
Heidegger'de Varolanlar ile Dünyanın İlişkisi Üzerine
}

\begin{abstract}
Öz
Heidegger metinlerinde varolanlara farklı adlar verir. Varolanların adları değiştikçe anlamları da değişir. Varolanların anlamları da dünya ile ilişkisinde açığa çıkar. Öyleyse varolanlarla birlikte dünyanın anlamı da değişir. Fakat bu değişmelere rağmen, varolanların anlamının her zaman Varlık ve dünya ile ilişkisinde açığa çıkması gibi, izini sürebileceğimiz benzerlikler de vardır.
\end{abstract}

\section{Anahtar Sözcükler}

Dörtlü, Sanat, Teknik, Şey, Varolan. 


\section{Giriş}

Bu makalede Heidegger'in varolanlara (Seiendes) verdiği adların değişmesinin anlamı, varolanlar ile Varlık ve varolanlar ile dünya ilişkisi üzerinden aranacaktır. Heidegger'de varolanlar kendilerinden yola çıkarak düşünülmezler. Onlar her zaman Varlıkla ilişkisinde düşünülürler; fakat Varlık da tek başına değil, hep ilişkilerinde/ilişkileriyle düşünülür. Bu bağlamda varolanların Varlık ile Dasein, Varlık ile logos, Varlık ile özdeşlik ilkesi ve Varlık ile hiçlik arasındaki ilişkilerde anlam bulduğu iddia edilebilir. Heidegger fenomenolojik bir yaklaşımla felsefe yaptığı için şeylerin/varolanların nasıl açığa çıktığını, hangi ilişkilerde görünür olduğunu sorar. Burada da varolanların anlamına fenomenolojik bir yaklaşımla ulaşmak istendiğinden, varolanların hangi ilişkilerde açığa çıktığı sorulmuştur.

Heidegger'in varolanlara verdiği adlar felsefe yaptığ tarihsel süreçte değişmiştir. Dolayısıyla Varlık ve Zaman'dan başlayarak varolanların adlarının, buna bağlı olarak da anlamlarının nasıl değişstiği izlenebilir. Fakat burada, Heidegger'in tüm metinlerinden yola çıkılacağı gibi bir iddia kesinlikle bulunmamakta olup, onun beş eseri seçilmiş ve soruşturma onlar üzerinden yürütülmüştür. Bu seçimde belirleyici olansa bu eserlerde varolanlara dair değişimin görülebiliyor olmasıdır. Böylelikle Heidegger'in varolanlara verdiği adlara dair dört dönem ayırt edilebilir: Varolanlar Varlık ve Zaman'da önümüzde hazır varlık (Vorhandene) ve kullanıma hazır varlık (Zuhandene); Tekniğe İlişkin Soruşturma'da el-altında-duran (Bestand); Sanat Eserinin Kökeni'nde araç (Zeuges), nesne (Ding) ve eser (Werk); Şey ve İnşa Etmek İskân Etmek Düşünmek adlı iki metninde de şey (Ding) adlarıyla karşımıza çıkar. Makalenin amacı, öncelikle varolanın değişen anlamlarını açığa çıkarmak, sonrasında ise varolanların aldığı farklı adların ve o varolanlarla/varolanlarda açığa çıkan dünyanın anlamlarının değişime uğradığını göstermeye çalışmaktır.

\section{Varlıkla İlişkisinde Varolanın Anlamları}

Şimdi varolanın anlamı Varlık ile Dasein, Varlık ile logos, Varlık ile özdeşlik ilkesi ve Varlık ile hiçlik arasındaki ilişkide aranacaktır. Böylelikle Heidegger felsefesinde varolan dendiğinde hem varolanın birden fazla anlamının olduğu hem de bu anlamların ilişkilerde açığa çıktığı görülebilecektir.

Varlık ile Dasein ilişkisinde varolan: Heidegger'e göre Varlık, varolanın anlamını belirler; çünkü varolanın varlığı, varolan değildir. Bu bağlamda Varlığın anlamını sorarken yapılması gereken ilk şey varolanın kökeninine başka bir varolanı koymamaktır. O halde Varlık sorusunu çalışmak demek, yanıtı Varlığın anlamı sorusunu soran varolanın kendi varlığı içinde aramak demektir. İşte bu soruyu sorana Dasein denir (VvZ, 5-7). Dasein öyle bir varolandır ki, Varlık anlayışına sahip olmak onun ontolojik belirlenimidir. "Dasein'ın “özü” kendi varoluşunda yatar” (VvZ, 12). Öyleyse varoluşsal olarak Varlığın anlamını soran Dasein, bu yanıyla diğer varolanlardan ayrılır. Varlığın anlamını sormayan, bu anlamın açılacağı Dasein'a benzemeyen varolanlar ise Dasein'ın Dünya-içinde-varlık olarak ilişkide olduğu varolanlardır: Önümüzde hazır varlıklar ve kullanıma hazır varlıklar. Dolayısıyla burada varolanın anlamı Varlık ile Dasein ilişkisine ait olup, Dasein'ın diğer varolanlardan 
farklı olmasında açılır. Varolanlar Dasein'ın dünya içinde karşılaştığı varlıklar olmakla belirlenir; bu karşılaşma ilişkisiyle anlam bulur.

Varlık ile logos ilişkisinde varolan: Heidegger'e göre varolanın varlığında karşıtlar arasındaki hareket, bir çatışma/savaş/mücadele/kavga (polemos) olarak düşünülür. $\mathrm{Bu}$ bağlamda logos, karşıtların çatışmasının böylece de birbirine ait olmalarının toplanmasıdır: Burada karşıtların çatışması bir arada kökleşmiş toplanmadır, logos’tur (VvD, 38). Logos'taki toplanma, sadece ylğma, birikme anlamına gelmeyip, uzaklaşıp ayrılan ve karşı çabalı bir birlikte-aidiyetin içinde olmadır. Bu bağlamda "Her şey akar” ifadesi, varolanın bütünlüğünün kendi varlığında bir karşıttan diğerine atıldığını, varlığında bu karşılıklı hareketin toplanmışlığı olduğunu dile getirir (MG, 154-155). Dolayısıyla Herakleitos'un 53. fragmanındaki çatışma, karşıtların birliğini oluşturan toplama olarak logos'la aynı şeydir. Bu çatışma tanrısal ve insansal olanın huzurunda işler ve böylelikle orada bir dünya oluşur. İşte bu dünya sayesinde hakikat (alethia) yani gizlenmemişlik (Unverborgenheit) açığa çıkar: Dünya sayesinde varolan varlaşır (MG, 73-74). Burada logos'un physis ile aynı anlama geldiği görülür. Varolanın varlığında ve Varlığın hakikatinde/gizli açık ilişkisinde taraflar arasındaki çatışma, bir ilişki/bağ olarak varolanları olmaya bırakır. Burada Varlık, varolanın varlığı olarak düşünülür ve varolanın varlığ 1 da logos'la ilişkisinde anlam bulur. Öyleyse varolan Varlığın hakikatinin açıklığı olarak, karşıtların çatışmasının toplanmasıyla açığa çıkan dünyada görünür olandır.

Varlık ile özdeşlik ilkesi ilişkisinde varolan: Heidegger, özdeşlik ilkesinden yola çıkarak aynılık ilişkisinde/A'nın kendi kendisiyle aynı olması ifadesinde, aynı olanın eşit olan olmadığını söyler; çünkü eşitlik ilişkisinde aralarındaki ayrılık kaybolur. Aynı olanda ise kendini açığa vuran bir ayrım vardır. İşte Heidegger'e göre hem bu ayrım hem de ayrımın iki tarafının birbirine ait olduğu unutulmuştur. Şimdi Varlık ile varolan arasındaki ayrıma bakıldığında, Varlığı varolanların genel kavramı, varolanları içine alan tümel bir kavram biçiminde sunmanın olanaksız olduğu görülür; çünkü Varlık yazgisal olarak şu veya bu özellikte bulunur (MV, 36-37, 49). Peki, Varlık ile varolan ayrımının içine sürülmesi gereken bu "ara" nereden gelmektedir? Heidegger'in yanıtı, "sahneye çıkış" (Ankuft) ile "açığa çıkarıcı üstesinden geliş" (Überkommnis) arasındaki ayrımda yatar. Sahneye çıkışın anlamı, "kendini aşikârlığın içinde gizli tutmak ve gizlenmiş olarak sürüp gitmek yani varolan olmak"tır. Varlık ise, "açığa çıkarıcı üstesinden geliş”tir. Bu durumda varolan olarak varolan, aşikârlıkta gizlenen sahneye çıkış olarak görünüşe gelir. Aralarındaki bu ayrım, içinde üstesinden geliş ile sahneye çıkışın birbirlerine tutturuldukları, birbirinden çıkarak birbirine taşındıkları o "ara" yı açık eder. Varlık ile varolan ayrımı, üstesinden geliş ile sahneye çıkış arasındaki ayraç olarak, bu ikisini açığa çıkartarak gizleyen aralıktır (MV, 45-48). Burada Varlık temel olurken, varolan da temeli kurulmuş olan olur. Üstesinden geliş ile sahneye çıkış, birbirlerinin içinde aksederek dışa yansır; Varlık ile varolan sürekli birbirlerine dönüp dolaşır (MV, 52-53). Dolayısıyla şimdi varolan, Varlığın özdeşlik ilkesindeki aynılık ilişkisinde, bu aynılıkta Varlıkla arasında oluşan ayrımda ve bu ayrımın sahneye çıkış ile üstesinden geliş olarak yeniden yorumlanmasında anlam bulur.

Varlık ile hiçlik iliş̧kisinde varolan: Heidegger'e göre Varlığın hakikatine yönelmek isteyen düşünme Hiçin araştırılmasıyla gerçekleşebilir; çünkü hiçlik de Varlığa aittir (MG, 100). Bununla birlikte Hiç, varolmadığı için anlama yetisiyle 


\section{0 KOIIII KOYQ 2017/28}

kavranamaz. Hiçle ancak tecrübede karşılaşılabilir. $\mathrm{Bu}$ tecrübe, kendini varolanın bütünlüğünün ortasında bulmaya benzeyen yeni bir varolma biçimi sunar. Varolanın bütününü kavramakla kendini varolanın bütünlüğünün ortasında bulmaksa birbirinden farklıdır. İlki olanaksızken ikincisi kendini günlük hayatın içinde, örneğin iç sıkıntısında bizi kaplar. Burada o, herhangi bir şeyden sıkılmakta değil, içimizi kaplayan derin iç sıkıntısında açığa çıkar. Kendini bu bütünlük içinde duyma hali bir de sevinçte söz konusudur. Fakat bu haller Hiçi gizler (MN, 30). "Varolandan-başka-olan-olarak duran Hiç, Varlığın peçesidir”. İşte Varlığın varolanda başka türlü, yani varolmayan olarak tecrübesini sağlayan, endişedir. Endişe Hiçle bağında ele alındığında psikolojik bir duygu değil özlü korkuya cesarettir ve endişe, Varlığın tecrübesinin gizemli imkanını kendinde barındırır (S, 46-47, 52). Endişede varolan bütünüyle kaybolur, içimizi kaplayan Hiçtir. Sarsılırız. Burada kendisinden veya kendisi adına endişelendiğimiz şeyin belirsizliğinin sebebi, onun belirlenebilirliğinin eksik olması değil, belirlenebilmesinin mümkün olmamasıdır. Böylece varolan kaybolur, hiçbir dayanak kalmaz. Varolan bütünlüğünde raydan çıkar, onunla birlikte biz de raydan çıkarız. "Vardır" sözünün anlamı ortadan kalkar. İşte şimdi Hiçin kendisi hiç olarak oradadır ve biz "hiçbir şey değilmiş" deriz. Peki, Hiç, endişede varolan olarak değilse ne olarak ortaya çıkar? Varolanla birlikte ne demektir? Burada endişe varolanı yok ediyor da geriye Hiç kalıyor değildir; Hiç, raydan çıkan varolanda açığa çıkar. "Hiçle, endişede, bütününde varolanla "birlikte" karşılaşılır". Hiçin varolanı raydan çıkaran işaret edişi hiçme- varolanı Hiçin karşısında açığa çıkarır (MN, 32-34). Varolanın raydan çıkışı, varolmayana yer açar. Varlığın varolmayışlı̆̆ı/varolmayan olarak Hiç, varolanlarla birliktedir, onlar birbirine aittir. Bu düşünüş Parmenides'in üçlü ayrımıyla (Varlık, hiçlik, görünüş) uyumlu görünmektedir. Endişenin endișe olarak tecrübesi, o kayboluşta kendini durdurabilme, Varlığın hiçlikle ilişkisine dair bir tecrübeye imkan sağlar. Şimdi varolanlarla bağın güvenliği, huzuru veya sıkıntısı yoktur. Varolanlarla bağımız koparken Varlığın varolmayışlı̆̆ıyla/Hiçle bağ kurarız. Burada varolan, endişede raydan çıkışı ve bu raydan çıkışıyla Hiçin tecrübesini mümkün kılışıyla anlam bulur.

\section{Varlık ve Zaman'da Varolanlar}

Varlık ve Zaman'da Varlığın anlamı aranır ve bu arayış Varlığın anlamını soran Dasein soruşturmasıyla temel bulur. Dasein aynı zamanda varolanların anlamının açıldığ 1 yerdir. Heidegger'e göre Dasein hep bir Dünya-içindedir (In-der-Welt-sein). Burada içinde-var-olmak demek, suyun bardağın içinde olması gibi bir şey değildir; çünkü Dasein varoluşsal (Existenz) oluşuyla diğer varolanlardan ayrılır (VvZ, 54-55). Yine, Dasein'ın Dünya-içinde bulunması, örneğin sandalyenin duvarın önünde olması gibi de değildir; çünkü bu durumda sandalyenin duvarla karşılaşabilir/tanışabilir (Begegnen) olması gerekirdi. Dolayısıyla Dasein için Dünya-içinde-olmak tinsel bir niteliktedir ve Dasein'ın mekânsallığı (Räumlichkeit), su ve sandalyede olduğu gibi cisimselliği üzerine temellenmez; çünkü bu metafiziksel bir düşünme olurdu (VvZ, 5758). Öyleyse Dasein'ın mekânsallı̆̆ı, önümüzde hazır varlıklar gibi mevcut bulunma veya kullanıma hazır varlıklar gibi kendi yerinde olma değil, mesafe-kaldırmaklık (Entfernung) ve istikamet (Ausrichtung) karakterindedir. Mesafe-kaldırmaklık demek, bir şeyleri yakınlaştırma, yakına taşıma, onlarla karşılaşmayı sağlama anlamına gelir (VvZ, 
108). Zaten Dasein özü gereği yönelmişlikle yani Dünya-içinde-varolmayla belirlenir. Dasein'ın burada bir-şey-için-bakışla (Umsicht) ilgilenmesi, belirli bir istikamete sahip mesafe-kaldırmaklıkla gerçekleşmektedir (VvZ, 113-117). O halde Dasein, içinde kendisinin şeylere dahil olduğu bir ilgilenme mekanını açması bakımından mekansaldır/uzamsaldır. Bu bizim kendi dünyamıza ait olduğumuz anlamına gelir; çünkü hep yönelir ve bir şeylere dâhil oluruz (Johnson, 2013: 36). Heidegger'e göre Dünya- içinde-varolmayla başlanmalıdır; çünkü ne önce kendimi sonra dünyayı ne de önce dünyayı sonra kendimi algılarım, aksine yaşantıda her ikisi de aynı anda çözülmez bir bağlantıyla verilmiştir. İşte buna "yönelmişlik" adını verir. Fakat Heidegger yönelimselliği Husserl gibi bilinç yapısı olarak değil, Dasein'ın dünya ile ilişkisi olarak kavrar (Safranski, 2008: 229). Dasein Dünya-içinde yönelimsel olarak diğer varolanlarla karşılaşabilen varlıktır; çünkü onlarla ilgilenmekte ve onlara yönelmektedir; onları aramakta, istemekte, bulmakta, kaybetmektedir. Dasein'ın varoluşa sahip olarak Varlığın anlamını sorması ve Dünya-içinde-bulunması, ona hem Varlık ile varolanlar arasında konumlanma imkânını hem de diğer varolanlarla karşılaşabileceği uygun mesafeyi sağlar.

Belirtmek gerekir ki Heidegger'e göre Dünya-içinde-olma Hıristiyanlığın anladığı gibi ilahi karşıtı fani veya tinsel karşıtı dünyevi değildir. Ona göre dünya, varolan ve uzamı/mekânı değil Varlığın açıklığı anlamına gelir (HÜ, 41). Dasein'ın dünya içinde yönelimsel bir varlık olması orada varolanlarla ve elbette diğer insanlarla ilgilenmesi anlamına gelir. Fakat Dasein'ın diğer insanlarla ilgilenmesi bu makalenin konusu dışında kalmaktadır. Dolayısıyla şimdi Dasein'ın ilgilendiği varolanların neler olduğuna bakmak yerinde görünmektedir.

Heidegger'e göre dünya içinde karşılaşılan varlıklardan olan kullanıma hazır varlıklar/el altında varlıklar (Zuhandene) birer gereçtir (Zeug) ve gereçlerle, örneğin çekiçle, ne ise öyle karşılaşılır. Burada bir özne-nesne ikiliği bulunmaz ve kullanıma hazır varlıklar bir şey için ilişkide, yani onları bir şey için kullanırken, insanın eyleminde açığa çıkarlar. Önümüzde hazır varlıklar/mevcut varlıklar (Vorhandene) ise bilişimin/bilgimin nesnesidirler. Burada özne-nesne ikiliği vardır ve önümüzde hazır varlıklar, öznenin bilmesine konu oluşlarıyla nesne konumundadırlar. Teorik davranış bir-şey-için-bakış değil, sadece seyretmedir ve bu haliyle kendine özgü yöntem(ler) geliştirir. Burada karşılaşılan varolandan hareketle keşfedici bir süreç yaşanır ve varolanın kendisinin varlığı önümüzde hazır olur. Kullanıma hazır varlık ve önümüzde hazır varlık olmaklık, varolanların ontolojik-kategoryal belirlenimidir (VvZ, 71-74, 91). Fakat belirtmek gerekir ki dünyanın yapısını belirleyen bu bağlar, dünyasız bir öznenin, karşılaştığı malzemeye yüklediği formlar ağı değildir (VvZ, 388). Bu ilgilenme bağları Dünya-içinde-varlık olarak Dasein'ın varolanlarla karşılaşma tarzlarıdır. Burada kullanıma hazır varlıklarla kurduğumuz ilişki yakın bir ilişkidir. Öyle ki bisikleti kullanırken düşünmeyiz, hatta tam da bunu düşünmeden onu kullanabildiğimizde gerçekten bisikleti sürmeyi öğrendiğimiz söylenir. Bu da aramızdaki mesafeyi kısaltır. Bizi onunla yakın kılar. Oysa önümüzde hazır varlıklarla teorik, bilinçli, zihinsel bir ilişkimiz vardır, onların karşısında özne olarak dururuz ve bu haliyle ilişkimiz böyle bir yakınlık ilişkisi gibi görünmemektedir.

İşte Heidegger'e göre kullanıma hazır varlıklar yakınlık karakterine sahip olup, bir-şey-için-bakışta, elle çalışma ve kullanımda ortaya çıkarlar. Buradaki yakınlık, 


\section{2 KOIIII KOYQ 2017/28}

fiziksel yakınlık veya onun bir yer işgal etmesi değildir. O kendisinde durur, o yer, gerecin bir-yere-ait-oluşunun oradalığı ve buradadılı̆̆ıdır. Onda nereyelik söz konusudur. Bütün nereyelikler her günkü ilişkimizin yol yordamıyla keşfedilip bir-şeyiçin-bakışla yorumlanmaktadır (VvZ, 106-107). Bu haliyle ilgilenedurduklarımız kamusal dünyadadır: Yollar, caddeler, binalar hep belirli yönde keşfedilir (VvZ, 73). Fakat önümüzde hazır varlıklar arasındaki nesnel uzaklık kullanıma hazır varlıkların mesafe ve yakınlığıyla örtüşmemektedir. Nesnel uzaklıkları biliyor olmak, eğer bir-şeyiçin-bakışın keşfedici yakınlaştırma işlevine sahip değilse kör bir bilgi olacaktır (VvZ, 111). Bir kapı örneğin, Heidegger'in ifadesiyle kullanıma hazır varlıktır. Eğer o kilitliyse ve ona kafamı çarparsam onu tahta levha olarak algılarım. İşte o zaman o benim için önümüzde hazır varlığa dönüşür. Ama bu durumda yani önümüzde hazır varlık oluşuyla, kullanıma hazır varlık oluşunun yaşanan anlamlılıkları kaybolur veya güçsüzleşir. Şeyler bu durumda nesne/kullanıma hazır varlık haline gelirler (Safranski, 2008: 232-323). Dolayısıyla kullanıma hazır varlık bilgimin nesnesi olarak benden uzaklaşmaktadır. Dolayısıyla Varlık ve Zaman'da, Dasein'ın Dünya-içinde yönelimselliği ve mekânsallığı ile ilişki kurduğu ve bu ilişkide anlam bulan iki tür varolanla karşılaşılır. Tüm bu karşılaşmalar ve ilişkiler ise Dasein'ın Dünya-içindevarlık olmasıyla gerçekleşir ve dünyanın anlamı da bu ilişkilerle açığa çıkar. Dasein dünyadan ayrı düşünülemediği gibi dünya da Dasein'dan ve onun ilişki kurduğu varolanlardan ayrı düşünülemez.

\section{Sanat Eserinin Kökeni’nde Varolanlar}

Sanat Eserinin Kökeni'nde Varlık ve Zaman'daki varolanların yanında yeni bir varolanla -sanat eseriyle- karşılaşılır. Heidegger sanat eserinin anlamına ulaşmak için sanatın ne olduğu sorusundan yola çıkar. Sanatın kökü olan tekhne sözcüğü Grekçeden gelmektedir. Burada iki şeye dikkat edilmesi gerekir. İlki tekhne'nin sadece el becerisine dayalı etkinlikler için değil, aynı zamanda zihinsel ve sanatsal etkinlikler için de kullanılıyor olmasıdır. Bu haliyle "tekhne, öne-çıkarmaya, poiesis'e aittir; o poetik bir şeydir”. İkincisi ise tekhne'nin episteme’yle, bilmeyle bir bağı olmasıdır. İkisi de bir şeyi anlamak, onda yeterli olmak, orada yurdunda olmak anlamlarına gelir ki bu haliyle bilme bir açılma sağlar; bu bir gizini açmadır. Tekhne, bu halde gizini açma olarak öne çık(ar)madır. Tekhne gizini açmanın (Entbergen) bir tarzıdır ve gizlilikten çıkmış olmanın yani hakikatin olup bittiği alanda vücut bulup sürer (TİS, 53-54). Öyleyse tekhne, bir yapabilme faaliyetinden farklı olarak, tecrübe edilmiş bir bilgi olarak varolanın ortaya çıkarılmasıdır (SE, 57). Burada bilmek bir çalışmanın biçimlenişinden önce onu karşısında görebilmektir (Nalbantoğlu, 1997: 13). Böylelikle Greklerde hakikati görünmenin 1şığı içinde öne çıkaran gizini açmaya tekhne denmekle birlikte, güzel olanda hakikatin görünmesine de aynı isim verilir. Orada sanatlar tanrıları buyur eder ve tanrısal ile insani yazgıların diyalogunu 1şıltılı bir parlaklığa büründürür. Burada sanat, hakikatin çok yönlü gizini açması olup tanrılara yakın durur (TİS, 79-80). Öyleyse tekhne öne çıkaran gizini açma olarak, bu gizin bir varolanda güzelce açığa çıkmasıdır. Bu gizini açmada hem tanrıların varlığı hem de insani ile tanrısal olanın canlı diyaloğu görünmenin içinde parlar. Böylece sanat, güzelin açıklığı olduğu için tek, tanrıları ağırladığı için de dindardır. Sanat sadece bir ürün verme etkinliği olmayıp 
hakikatin açıklığına yönelik bir bilme etkinliğidir. Bir hakikat olayı olarak sanatın ortaya çıkardığı varolan ise sanat eseridir; sanat, sanat eserinde açığa çıkar. Sanat eseri ise nesne ve araçtan farklıdır.

Heidegger öncelikle eserin bir nesne olup olmadığına bakar ve üç farklı nesne yorumuyla karşılaşır. Bunlar duyularla verilmiş olanların çeşitliliğinin birliğí, biçimlenmiş malzeme ve özelliklerin taşıyıcısı olarak nesne yorumlarıdır (SE, 19-20, 24). Nesne soruşturmasıyla araç (des Zeuges), nesne (das Ding) ve eser (das Werk) ayrımlarına ulaşan Heidegger aralarındaki farklılıkları şöyle dile getirir: Araç, nesne ile eser arasında kendine has bir konuma sahiptir (SE, 23). Aracın araçsallığı, onun araç olarak gerçekleştirdiği hizmetselliğinde yatar. Fakat aracın, örneğin ayakkabının, araçsal varlığı, burada hizmetselliği, ayakkabıya bakarak anlaşılmaz. Aracın hizmetiyle sunduğu ise güvenilirliktir. Dolayısıyla hizmet ederek aşınan araç hem hizmetselliğini hem de güvenilirliğini yitirir. Böylece o araç bir nesneye dönüşür (SE, 26-28). Araç, kullanıma hazır varlık olarak işimize yarayan şeydir. Ne ki bir şeyler ters gider, hizmet aksar, o zaman o önümüzde hazır varlık olur, nesneye dönüşür. Dolayısıyla burada araç ve nesnenin, Varlık ve Zaman'daki varolanlarla benzerliği ortadadır.

Sanat eseri ise, yaratılmış olmanın varlığının saf olarak ortaya çıktığı şeydir (SE, 62). Eser, eser olarak kendisi aracılığıyla açılan alana, hakikatin güzelce açılmasının alanına aittir. Eserin eser varlığı yalnızca ve yalnızca bu açılımda bulunur. Örneğin Grek tapınağında "açılan nedir?" dediğimizde görürüz ki, öncelikle tanrının tapınak sayesinde tapınakta açığa çıktığı görülür. Bu açığa çıkış, alanın sırrı ve genişliğidir. Bunun yanı sıra tapınak, doğum ile ölümü, felaket ile kutsallığı, ihtişam ile sefaleti, yükselme ile çöküşü, böylece insan yazgısının biçim kazandığ toplayıp bir araya getirir. $O$ halde orada açığa çıkan, tarihsel bir halkın dünyasıdır. Böylelikle tapınak, kendi duruşunda, nesnelere sahip oldukları çehreleri ve insanlara da bakışı verir. Tapınak eser olduğu ve tanrı oradan ayrılmadığı sürece bu bakış açık olarak kalır (SE, 36-38). Görülüyor ki araç, nesneyi/malzemeyi hizmete sokar ve bu sırada nesne yok olurken, sanat eserinin dünyasında malzeme bütün ihtişamıyla yükselir. Burada eser, estetik değerlerle donatılmış bir araç olmadığı gibi nesneden de farklıdır. Eser, mekân olarak bir dünyanın açılmasıdır (Tepebaşı11, 2011: 106-107). O halde eserin eser varlığı, bir açıklıkta açığa çıkışında bulunur. Bu açıklık, bir dünyanın açıklığıdır. Eser ilişkilerin birliğidir; çünkü ilişkileri toplayarak bir açıklıkta dur(dur)ur. Bu haliyle eser hakikatin/yazgının tarihsel olarak görünür olmasıdır. Eser ayrıca, ona bakanı bir dünyaya davet eder. Öyleyse eser, eserdeki varlıklar orada kaldığı ve belki bir göz onları seyrettiği sürece eser olarak kalır ve nesneye dönüşmez. Eserdeki dünyanın açığa çıkmışlı̆̆ ise yeryüzünün gizlenmişliği ile birliktedir.

Hakikat varolan olarak varolanın açıklığıdır. Hakikat kendini koyarsa gözükür, gözükmek ise güzelliktir. Böylece güzel, hakikatin gerçekleşmesine ait olur (SE, 79). Öyleyse sanat eserinin özü hakikatin/doğruluğun esere konması biçimindedir. Fakat esere güzellik sonradan konulmaz. Tersine eser, güzel olarak tam da hakikatin onlara konma süreciyle meydana gelir. Eserin yapılması demek, dünyanın sergilenerek oraya konması ve aynı zamanda yeryüzünü de oraya koymaktır (Sözer, 2010: 55-56). Bununla uyumlu olarak Grekler kendinde ve bütünde doğuşa physis derler. İşte eserde rüzgâr, gök, ihtişam açığa çıkar. Böylece sanat eserinin kendi barınağını kurduğu yer yeryüzü demektir; eserde yeryüzü açığa çıkar. O, doğmakta olanların doğumunu kendileri olarak 


\section{4 KOIIII) KOYQ1 2017/28}

gizleyen şeydir; yeryüzü, gizleyen olarak hem doğmakta olanlarda bulunur hem de dünyayı çevreleme ve öylece tutma eğilimindedir (SE, 37-39). O halde eser, yeryüzünü yeryüzü kılar. Yeryüzü burada kendisine girme denemelerini engelleyerek, açıklama denemelerine de kendini kapatır ve böylece korunduğu yerde daha açık olarak ortaya çıkar (SE, 41-42). Böylece eser bu şeylik özelliği ile yeryüzüne ait olur (Altuğ, 2012: 154). Burada yeryüzü mitosla karışık, ilksel bir anlamdadır; o her şeyi kuşatan, beslenme, barınma, hayat kaynağıdır (Quigley, 2008: 327). Dünya, yeryüzüne karşıt olarak kurulur ve o, insan Dasein'ının öz yorumunda sezgisel açıklığa ulaşabilirken yeryüzü gerçek yerini şiir dünyasında bulacak olan mitolojik ve gizemli bir seda verir (Gadamer, 2010: 135-136). Yeryüzü eserde gizleyen olarak eserin kapanmışlığıdır ve böylelikle de hakikatin eserde açığa çıkmasını/dünyayı mümkün kılar.

Hakikat aydınlık ile gizlenmenin en eski kavgası olduğu sürece yeryüzü dünyadan yükselir, dünya da yalnızca yeryüzünün üzerine kurulur (SE, 49-50). İşte eser dünya teşkil ederek ve yeryüzü kurarak bu kavgayı/çatışmayı yürütür (SE, 44). Eserin açığa çıktığı çatlak (Riss) çatıdır. Çatlak ve çatışmanın kökü olan "çat" sesi kırılma, ayrılma, birleşme anlamlarının yanı sıra iki derenin birleştiği veya yolun ikiye ayrıldığı yer anlamlarına da gelir. Ayrıca o, çatının da kökü olarak çatılı olma, birbirine bağlanmış olma anlamlarını da kendinde taşır. Şimdi çatlak sözcüğünü sanat eseri için yorumlarsak, eserin bir ara (Zwischen) olduğunun söylendiğini görürüz. Eser, dünya ile yeryüzünün arası ve 1şığa çıkma ile karanlığa girmenin birbirine aralandığ1 aradır, burada olandır (Sözer, 2010: 56). Dolayısıyla eser yeryüzü ile dünya arasındaki çatışmayı bitirmediği gibi onu sürekli de kılar; eserin birliği bu çatışmada kurulur. İşte hakikat tam da bunun sürmesiyle gerçekleşir (Tepebaşıl1, 2011: 108). Heidegger'in örneğinde Vincent van Gogh'un resmi yalnızca köylü kadının dünyasını ve yeryüzünü değil aynı zamanda genel olarak insanın dünyasını ve yeryüzünü de açığa çıkarır (Singh, 1990, 216). Dolayısıyla Varlığın hakikati gizli ile açık bağıyla, eserde yeryüzü ile dünya bağıyla, yeniden kurulur ve eser de yeryüzünün yeryüzü olarak, kendi kapalılığında görünmesini mümkün kılar, bunu da yeryüzünün dünya ile çatışmasında yapar. Böylece eserde bir dünya açılır. Bu dünya her zaman bir halkın dünyası olarak tarihsel bağlamlara da sahiptir. Heidegger'e göre bu açıklık, sanat eserinde hem olan ve bilinen bir dünya yerine, olmakta olan ve gizemli bir dünya açarak (Errichtung) hem de eserin açtığı açıklıkta şeyleri kendi olmaya çağırıp bunun için onlara yol olarak (Herstellung) gerçekleşir (Kurtar, 2014: 177). Dünya ile yeryüzü arasında bir çatlak/yarık, açıklık, gerilim, bağ vardır ve onlar bu gerilimde kendileri olurlar, yani bu çatışmanın tarafları olarak birbirlerine ait oluşları içinde, bu ilişkide anlam bulurlar. Dolayısıyla burada hem çatışma hem de birlik vardır. İşte sanat eserinin insan yazgısına/hakikate dair tüm ilişkileri toplaması bu çatışma sayesindedir. Burada dünyanın anlamı üç tür varolandan araç veya nesnede değil sanat eserinde açığa çıkışıyla anlam bulur.

\section{Tekniğe İlişkin Soruşturma'da Varolanlar}

Teknik kökensel olarak, sanatın da dayandığı gibi, tekhne'ye dayandırılabilir. Tekhne, gizini açmanın bir tarzı olarak hakikatin açıklığında durur. Fakat modern teknikteki hâkim gizini açmada, doğaya enerji sağlaması için söküp alınabilme, 
depolanabilme şeklindeki talebi dayatan bir meydan okuma söz konusudur (Herausforden). Burada örneğin bir toprak parçası gizini maden yatağı olarak açar veya itinayla düzene sokulan (Bestellen) tarla başka türlü görünür (TİS, 55). Meydan okuyucu gizini açmanın kilit altından kurtarma, dönüştürme, depolama, dağıtma gibi süreçleri de gizini açmanın tarzları olsalar bile düzenleme ve güvence altına alma, meydan okuyucu gizini açmanın temel karakteristikleridir (Tís, 58). Bu (teknik) düşünmede makine, canlının yerine geçer ve artık canlılar makine olarak kavranır, zaten her türlü biyoloji de bu yolda iş görmektedir (TM, 11). Burada tekhne'nin anlamı ciddi şekilde değişir. Öncelikle şimdi onun doğayla/varolanlarla kurduğu ilişki biçimi tamamen yenidir. Doğa artık kendi giziyle birlikte açığa çıkan değil, kontrol edilen, zaptedilen, düzenlenen ve kontrol edilerek güvence altına alınan bir şeye dönüşür. Doğa tüm anlamlarını bu ve benzeri bağlarda açar. Yani doğa ondan talep edilen hatta ona dayatılan isteklere uygun olup olmamayla görünür hale gelir. Bununla birlikte canlılığın da anlamı değişir; mekanik tasarım iş başındadır.

$\mathrm{Bu}$ tarzda düzenlenen her şey kendine özgü bir duruşa sahiptir ve Heidegger ona el-altında-duran (Bestand) adını verir ${ }^{1}$. Burada insana doğa enerjilerini sömürmek için meydan okunduğu ve insan bu sömürüyü yapmak için düzenlendiği ölçüde, insan da elaltında-durana dönüşür (TİS, 58, 60). Böylece insan çerçeveleme içinde tamamen elaltında-duran içinde emilebilir ve Dasein olarak değil fakat kendisini kullanıma hazır bir araç olarak bilen salt bir kendinin-bilincinde varolan olarak açığa çıkabilir (Özlem, 1998: 28-29). Bu ise tam da insanın da sömürülmesi anlamına gelir; çünkü artık insanın olası açığa çıkma imkânları örtülmekte ve insandan kendini tek bir tarzda açığa çıkarması beklenmektedir. Doğanın başına gelen, insanın da başına gelir. İnsan da artık amaç için araca dönüşür ve bu haliyle kullanıma hazır varlıklarla aynı ontolojik statüyü paylaşır. İnsan kendi varoluşsal zeminini kaybederek varolanlardan biri olur. Kaldı ki insan ve doğa dâhil tüm varolanlar artık nesne olmayıp el-altında-durana dönüşmüştür.

Heidegger insanın, kendi gizini açanı el-altında-duran olarak düzenlemek için oraya toplayan meydan okuyucu talebini çerçeveleme $(\mathrm{Ge} \text {-stell })^{2}$ diye adlandırır. Çerçeveleme, düzenleme (Stell) tarzı içinde real olanın gizini el-altında-duran olarak açmak için insana saldıran, meydan okuyan saldırının bir araya toplayıcısıdır (Ge) (TİS, 62-63). ${ }^{3}$ Heidegger çerçeveleme içinde hüküm süren yazgının gerçekten tehlikeli olduğunu söyler. Yazgının tehlikeli olması ne anlama gelmektedir? Bu tehlike kendini

1 Bestand, bestehen fiilinin süregitmek ve kalıcı olmak anlamlarını taşır. $\mathrm{O}$ daha çok nesnelerin düzenlenebilirliğini ve ikame edilebilirliğini vurgulamak ister. Modern teknikte böyle şeyler el-altında-duran halindedir. Aynı zamanda Bestand, Gegenstand'ın karşıtıdır. Modern teknikte karşıda-duran olmaktan çıkıp el-altında-duran olur, nesne olma karakterini yitirir, nesne el altında durana dönüşür (Özlem, 1998: 59).

2 Heidegger Gestell'den modern teknolojinin özü olarak bahsetmesini büyük ölçüde Jünger’in Gestalt'1, her şeyi endüstriyelleşmiş insanlık için “daimi kaynak" (Bestand) olarak açığa çıkaran ontolojik ilke şeklinde kavrayışına borçludur. 30 ve 40'lar boyunca Heidegger Gestalt'1 yaygın olarak kullanır (Zimmerman, 2010: 271).

3 Ge-stell, temelde bir çağrı, meydan okuyucu talep, davettir. O gizini açacak şekilde toplayandır. Bu talep, bir araya getirdiği ve düzenlediği için çerçeveler. Davet ettiği her şeyi kullanım düzenlemesiyle bir çerçeve, şekillenme içine sokar. Ge, bir araya toplama işlevi görür, burada vurgu işlevlendirmeyedir (Özlem, 1998: 62). 


\section{6 KOIIII KOYQ 2017/28}

iki biçimde gösterir: Öncelikle insan gizinden çıkanı nesne değil, el-altında-duran olarak gördügü an, insan da el altında olanı düzenleyen olur ve onunla aynı noktaya iner. İkincisi ise insanın her şeyi düzenlemesi sebebiyle kendini yeryüzünün efendisi konumuna yükseltmesidir. Böylece insan karşılaştığı her şeyin kendi ürünü olduğu izlenimine kapılır ve daima her yerde yalnızca kendisiyle karşılaşıyormuş gibi görünür ki, bu da yanıltıcıdır. Çerçeveleme yazgı olarak insanı, düzenleme olan gizini açmaya sürgün eder ve bundan başka bir imkânı da defeder. Çerçeveleme aynı zamanda poiesis anlamında, şeye görünüşe çıkma imkânı veren gizini açmayı da gizler (TİS, 71-72). Böylece çerçevelemenin saldırısı şeyin önüne geçer ve önüne geçtiği şeyi hakikatsiz bırakır; çerçeveleme yalnızca yakınlaşmakta olan dünyayı tanınmaz kılmakla kalmaz, bunu yapıyor oluşunu da tanınmaz kılar (D, 56). Öyleyse çerçeveleme olarak teknoloji, kendisi dışındaki tüm açığa çıkma imkânları için bir sınır olur ve dünyaya dair farklı tecrübeleri örter (Aşkın, 2011: 42). İşte çerçeveleme varolanların bir tasarım içinde, istenen amaçlar doğrultusunda açığa çıkmasını dayatarak bunun dışındaki açığa çıkma imkânlarına engel olur. Bununla da kalmaz, onun başka türlü açığa çıkabileceğini düşüncesini de ortadan kaldırır. Yani kendi bakışını tekleştirir. Bu ise bir olumsuz sonuç daha doğurmaktadır ki o, çerçevelemenin Varlığın açığa çıkma tarzlarını örtüyor oluşunun da örtülmesidir. Böylece iki tür kapalılıktan söz edilebilir. Doğanın istenen çerçevede kendini açmaya zorlanması ve bu zorlamanın kendi biricik yeni hakikatini ilanı.

İnsan ile Varlığı, değişimli olarak birbirlerini temsil edecek biçimde birbirine çatan çağrı olan çerçevelemede, Varlığın çağrısı insanı varolanları hesaplanabilirlikte görünüşe getirmeye çağırır (Öİ, 21-22). Hesaplanabilirlikte açığa çıkarma olan hesaplama ise tüm varolanı sayılabilen olarak önceden kullanır ve sayma için sayıları tüketir (S, 48). Bunların ortasında insan kendini varolanlara efendi kılar. Burada tüketim tek yol olarak görülür. Bununla birlikte insan da tıpkı tükettikleri gibi bir hammadde olup sadece en önemli hammaddedir; çünkü tüketimin öznesi odur (MÜ, XXVI). Burada kontrol ve yönetme insana değil tekniğe aittir. Dolayısıyla teknolojiyi yönetme hamlelerimiz sadece onu güçlendirmekle sonuçlanır. Şimdi teknolojinin özüne dair elimizdekiler şöyle sıralanabilir: Öncelikle o bizim yaptığımız bir şey olmayıp Varlığın açığa çıkma tarzlarından biri olarak parça ile bütün arasındaki ilişkileri bu tarzda açar. İkincisi, tanrı veya tarih gibi teknolojik olmadığını sandığımız varlıkları da içerir. Üçüncüsü, fabrikalaşma ve endüstriyel ilerleme zamanında açığa çıkar. Sonuncusu ise, doğa bilimlerinin pratik uygulaması olmayıp, aksine modern doğa biliminin, doğanın ölçülebilirliğiyle anlaşılmasıdır (Blitz, 2014, 69-70). Burada çerçevelemenin daha önceki anlamlarıyla uyumlu biçimde hesaplayıcı bir düşünme anlamına da geldiği söylenir. Hesaplayıcı düşünme çıkara uygun olarak amaca hızla yönelir ve koşulsuzca ilerler. Şimdi artık ne özneden ne de insandan söz edilebilir. İnsan da dâhil tüm varolanlar el-altında-durana indirgenmiştir. Burada el-altında-duran sanat eserinde olduğu gibi hakikate dair ilişkileri toplamanın aksine hakikate dair ilişkileri örterek onun ışığını karartır. Dünyanın anlamı her şeyin kontrol altında olduğu yanılsamasıyla düşünülür. Dünya burada el-altında-duranların toplamıdır. 


\section{5. Şey Ve İnşa Etmek İskân Etmek Düşünmek’te Varolanlar}

Heidegger, "Yeryüzü ve gökyüzünün, tanrısal olanlar ve ölümlülerin sade birliğinin olageldiren ayna-oyununu ${ }^{4}$ dünya olarak adlandırırız" der. Burada dörtlünün (Geviert) birliği dörtlemedir; fakat dörtlemenin ayna oyunu onları çevreleyen, onlara sonradan eklenen, onların ayrı ayrı duruşlarında kendini tüketen bir şey değildir. Dörtleme ayna oyunu, dünyanın dünyalaması olarak özünü sürdürür (Ş, 160-161). Dünyanın dünyalaması insanın kendini ve şeyleri anlamasını bağışlar; anlamın açıklığını/açılmasını sunar (Singh, 1990, 216). Dörtlü birlik bire aittir. Yani örneğin yeryüzü denince diğer üçü düşünülür ve diğerlerinin her birinde de öyle yapılır. $\mathrm{Bu}$ dördün basit birliğine dört katlılık denir. İşte ölümlüler/insanlar bir parçası oldukları bu dörtlüyü asli vücuda gelişleri içinde güvence altına alacak tarzda ikamet ettikleri (Wahnen) takdirde o dörtlü birliğe ait olurlar: Ölümlüler yeryüzünü koruyup gözettikleri, göğü gök olarak gördükleri, tanrısal varlıkları tanrısal varlıklar olarak bekledikleri ve kendi asli varlıkları ölüm(lülük)le karşılaştıkları kadarıyla dünyada ikamet ederler (İ, 80-82). Demek ki bu dünyadaki ikametimiz, dünyanın dünyalığını/ayna oyununu yani dört katlılığını/dörtlü birliğini anlamakla başlayacaktır. $\mathrm{Bu}$ ise, bu birliğin her birini olduğu haliyle karşılayabilmek demektir. Kendimize dair öne çıkan özelliğimiz ise ölümlü oluşumuzu anlamamızdır. Bu dünyada ikamet etmek demek orada barınmak ve bir şeyler inşa etmek anlamına da gelir. Heidegger köprü örneğinden yola çıkarak inşa etmenin anlamını açar.

Heidegger'e göre insanın ikamet etmesi inşa etmeyle birliktedir; çünkü eğer ikamet etme bu dörtlüden ibaret olsaydı ölümlüler asla muktedir olamazdı. Tersine ikamet etme bir şeylerle kalmadır. Öyleyse ikamet etme dörtlüyü şeyler içinde muhafaza eder. İkamet etme bunu nasıl yapar? İnşa etme hangi bakımdan ikamet etmeye aittir? Yanıt köprü örneğiyle verilir: Köprü üzerine kurulduğu akarsuyu, onun kıyılarını ve birleştirdiği kara parçalarından her birini diğerinin komşuluğuna getirir. Böylece köprü dörtlüyü kendinde toplar ve köprü bunu bir şey olarak yapar (İ, 83-85). Dolayısıyla bu dünyada ikamet etme, inşa etmeden ayrılamaz ve her ikisi de doğadaki şeyleri kendi varlıklarında tutar. Bu bağlamda ölümlüler yeryüzünü kullanmayı değil orayı korumayı öğrendiklerinde orada ikamet ederler (Gray, 2008: 283). Heidegger burada dünya içinde bulunma tarzımızı açmaktadır. Aslında dörtlü birliğin her birinin kendi açıklığında görünmelerinin imkânı, bu dünyadaki şeylerle ilişkimize, dünyada inşa etme ve ikamet etme tarzımıza bağlı olmaktadır. Başka türlü söylenirse inşa ettiğimiz şeylerin kendi şeyliklerinde anlaşılıp anlaşılamamasıyla ilgilidir. Örneğin çocuğumuzun oynayacağı bir bahçe yaparız, inşa edilen bu yerde, çocuk ikamet ederken, çocukluğunu da yaşar ve aynı zamanda çocukluğunu inşa eder. İnşa edilen yerdeki/mekândaki ikamet, orada oluşu/oluşları inşa etmek anlamına da gelir.

Dolayısıyla insan ile mekân arasındaki ilişki, ikamet etmeden başka bir şey değildir. Mekân dörtlü için evdir. Bu bağlamda dörtlüyü koruma, orada ikamet etmenin basit özüdür. Bunu da inşa ettiklerimizde yaparız. Dolayısıyla inşa etmenin özü ikamet etmededir. İkamet etme Varlığın asli mahiyetidir (İ, 92-95). İnşa etmenin özü ikamet

4 Heidegger bu ifadeyle hem dörtlünün her birinin diğeriyle ilişkisinde anlam bulduğu hem de dörtlünün her biri düşünüldüğünde orada diğer üçünün de görünür olduğunu dile getirir. 


\section{8

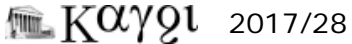

etmedir, ikamet etmenin özü de dörtlüyü korumadır; çünkü insan ancak o zaman şeyi şey olarak görüp, onun yakınlığına sokulup, oraya aitliğini anlayıp, oradaki dörtlü birliği tecrübe edebilir. Yine inşa etmenin özü ikamet etmededir; çünkü dörtlü birlik ancak bu inşa edilende ikamet ederek açığa çıkar ve böyle görünür, karşılaşılır, anlaşılır olabilir. Burada mekân dörtlünün açılacağı açıklığı sunar. Zaten Varlık ve Zaman'da bize Dasein'ın Dünya-içinde-bir-varlık olduğu söylenmiştir. Yani orada da bir insan önce var olur sonra dünya ile ilişsilenir demiyorduk, bununla uyumlu olarak şimdi de insan ile dünya ilişkisinde insan o dörtlüde ikamet eden, orada inşa ederek ikamet etme imkânına sahip olandır. İnsanın mekânı dünyadır, imkânı da oradadır.

Köprü dörtlüyü bir şey olarak topladığına göre şimdi de şeyin anlamı sorulabilir. Şeyle yakınlık nasıl mümkün olur? Heidegger'e göre yakınlıkla dolaysızca karşılaşmayız, yakın olanlara ancak kulak vererek yakınlaşabiliriz. İşte yakın olanlarsa şeylerdir. Örneğin bir testi bir kaptır. Fakat testiyi üretilmiş bir kap olarak ele aldığımızda testi şey olmak yerine nesne olur (Ş, 152-153). Bu bağlamda bilimsel tasarımlamayla şarap sıvı haline gelir ve sıvılık da maddenin hallerinden birine dönüşür. Peki, testi şey olarak boşluğu nasıl kapsar? Burada kapsamak hem almak hem de tutmak anlamlarına gelir. Almayı ve tutmayı birbirine ait kılan ve bu birliği sağlayan da taşmaktır. Taşmanın armağanı, ölümlülere su ve şenlik veya tören için içecek olmasıdır. Taşmanın armağanında ölümlüler, tanrısal olanlar, yer(yüzü) ile gök(yüzü) kendi tarzlarında hep birlikte dururlar, birbirlerine ait olurlar. Testi, bir dünya açmasına ve dörtlüyü toplamasına rağmen taşmanın armağanında, testi olarak özünü sürdürür. Zaten Almancada bir araya toplama eski bir sözcükle Thing'dir (şeydir). İşte şey de dörtlüyü toplar. (Ş, 155-157). Öyleyse testi armağanda şey varlığını yitirmez. Bu onun hem önümüzde hazır, kullanıma hazır veya el-altında-duran olmayacağı anlamına hem de çerçevelemedeki gibi bir yapıda erimeyeceği anlamına gelir. Türkçede de şey, bir belirlenmemişliğin belirlenmişliği anlamına gelir ki bu haliyle o, anlam alanını kendinde kurar/toplar. Şey burada sanat eserine de benzetilebilir; toplar ve açar.

Şeyin dörtlüyü toplaması ise şu şekilde gerçekleşir: Şey, dörtlüyü uzaklıklarında birbirinin yakınına getirir. Yakınlık uzaklığ 1 koruyarak yakına getirir. "Şey, dörtlüde durakalır. Şey dünyayı şeyler”. Yani şeyi şey olarak düşünürsek onun özünü koruruz. Şeylemek demek dünyanın yaklaş(tırıl)masıdır, bu da yakınlığın özüdür. Yakınlığın yaklaştırılması dünyanın ayna-oyununun tek ve asıl boyutudur. Bugün tüm mesafeler ortadan kalkmış fakat yakınlık kendine yer bulamamıştır. Bu da mesafesizi hâkim kılmıştır. Burada şey, şey olmaktan çıkar; çünkü şeyin özü yakınlığın açığa çıkmasıdır. Mesafeler ortadan kalkınca yakınlık ile uzaklık da ortadan kalkacağından artık bir yakınlık alanı kendini şeyde açamayacaktır (Ş, 159-162). Yakınlık elbette uzaklığın yakınlığıdır. Yani eğer bir şeyin yakınlığından söz edeceksek onun öncelikle uzak olması gerekir. Bir uzaklığı taşımıyorsa kendinde, yakına da gelemez. Arada bir mesafe vardır ve o alınır. Şeyler el-altında-duran, kullanıma hazır/araç, önümüzde hazır varlık/nesne olduğunda, yani şey, bunlardan birinin mührüyle damgalandığında artık kendi özgürlüğünde/açıklığında açığa çıkma şansını kaybeder ve onunla bu yakınlık ile uzaklık bağı kurulamaz. Eğer şeylerle açığa çıkma/görünme üzerinden bir ilişki kurulmazsa, onların yakınlık ile uzaklıklarından da söz edilemez. Heidegger'in ilk döneminde şeyler yoktur, şimdiyse onlar dünyayı dünya olarak açar. 
Dörtlü birliğin birbiriyle nasıl karşılaşmasının nasıl anlaşıldığı sorusunun yanıtı ise dildir: Dörtlü birliğin bileşenleri dilde karşılaşırlar; dil dünyayı devindiren söyleme olarak, bütün ilişkilerin ilişkisidir. Dolayısıyla dilin karakteri, dünyanın dört alanının yüz yüze geliş hareketinin karakterine sahiptir. Burada yakınlık, kendisini dünyanın bölgelerinin birbiriyle yüz yüze geldiği devinim durumu olarak açar (DD, 42). Öyleyse şeylerin dörtlüyü toplaması da dil sayesindedir; çünkü Heidegger'e göre adlandırma çağırır. Çağırma çağırdığı şeyi yakınına çağırarak onunla buluşur. Adlandırılan ve böylelikle çağrılan şeyler kendilerini dörtlüde bir araya getirir. $\mathrm{Bu}$ şeylerin şeyleşmesine/şeyin şey varlığına ve buradaki dörtlünün birlikte ikametine dünya denir. Fakat dünya ile şeyler varlıklarını yan yana sürdürmezler, onlar birbirlerine nüfuz ederler. Bunun için de bir orta alanı katederler. Orada birbirlerine yakın ve birdirler. Bunun anlamı ikisinin arasının/ortasının yakınlık olması demektir. Dolayısıyla yakınlık, şeyler ile dünyanın kendilerini ayırdığı yerde söz konusudur. Dünya ile şeylerin yakınlığı, aranın ayrımında varlık kazanır, o farklılıkta, aralarında birbirlerine yönelecekleri o ayrım alanında açığa çıkar. Dünya ve şeyleri çağıran buyrukta, aslında çağrılan farklılıktır. Farklılık, şeyleri şeyler olarak dünya içinde, dörtlüde sessizleştirir (DL, 59-61). Örneğin keder diye bir şeyin anlamından söz ediyor olmamızın nedeni dildir. Ona "keder" adını vermemiz, onu diğer sözcüklerden ayırmamız, böylece onu varlığa çağırmamızdır. "Keder" diye bir ad vermeden keder diye bir şeyin var olup olmadığı sorusu ise anlamsızdır, çünkü "keder" sözcüğü soruda geçmektedir. Böylece söz varlığa çağırmaktadır ve bunu ad vererek yapmaktadır. Oysa şeyler zaten vardır. Şeylik onların ad verilmemişliğinin adıdır. Dünya ile şeyler elbette yakındır; çünkü dünya şeyde ve dilde bir birlik halinde açığa çıkmaktadır. Bununla birlikte şey, şey varlığını ve dörtlünün dansının varlığını dile borçlu değilse de o dörtlüyü toplamasının anlamını dile borçludur. Demek ki şey ile dünya arasında bir ayrım da vardır; çünkü şey, dünyanın açıklığı, dil ise şeyin açıklığıdır.

\section{Sonuç}

Heidegger'de varolanın “anlamı” Varlığın ilişkilerinde açığa çıkar demek, varolanın kendisinden yola çıkarak bir “özü”nün olduğunu söylememek demektir. Varolanın anlamının ilişkilerde açığa çıkması aynı zamanda Heidegger'in hakikat ve yazgı anlayışıyla da uyumludur. Varolan her zaman Varlıkla bağında ve tarihsel bir bağlamda görünecek ve bu görünme kendi içinde gizliliği de taşıyacak demektir. Varolanın anlamının değişmesi, ona verilen adların değişmesiyle karşılıklı bir ilişki içindedir; yani hem varolanın anlamı öyle açığa çıktığı için o ad verilir hem de o ad verildiği için varolanın anlamı öyle açığa çıkar. Bu bağlamda varolanların adlarının değişmesiyle orada açığa çıkan dünyanın anlamlarının da değiştiği görülür.

Varlık ve Zaman'da dünya, Dasein'ın içine firlatılmışlığıyla/Dasein'ın Dünyaiçinde-varlık oluşuyla ilişkisinde anlam bulur. Burada varolanlar da Dasein'ın ilişkilerinde kendi varlık tarzlarını açarlar. Dolayısıyla Dasein, dünya ve varolanlar birbirlerinden ayrı değildirler. Sanat Eserinin Kökeni’nde dünya yeryüzüyle çatışması bağlamında karşımıza çıkar. Eserde hakikate dair bir görünme meydana gelir; yeni bir dünya açılır. Burada dünya bir yüzüyle tarihsel bir halka ait olup diğer yüzüyle Varlığın hakikatine dairdir. Burada eser, varolanlardan biri olarak hakikatin açıklığında durur. 
Oysa daha önce bunu, varoluşuyla diğer varolanlardan ayrılan Dasein'ın yaptığı söylenmiştir. Şimdi Dasein'ın yerini eser almış gibidir. Tekniğe ilişkin Soruşturma'da dünya Varlığın teknik düşünme/çerçeveleme içinde örtülen hakikatinin açıklığıdır. Burada tüm varolanların el-altında-duran olması ve onlara tek bir tarzda açığa çıkmanın dayatılması dünyanın da hesaplanabilir hammaddeler toplamı diye düşünülmesine sebep olur; dünya bir tasarıma/resme dönüşür. Şey ve İş̧a Etmek İskan Etmek Düşünmek adlı iki metninde ise dünya ölümlüler ile tanrılar ve gökyüzü ile yeryüzünün oyununda/dansında açığa çıkar. Burada varolana şey denmekte ve şeyin şey varlı̆̆ dörtlü birliğin görünür olma zemini olarak karşımıza çıkmaktadır. Şey, tüm varolanların ilişkisel bütünlüğünü kendinden toplarken el-altında-duranın tam aksi gibi görünür. $\mathrm{Bu}$ haliyle eser şeye benzetilebilir.

Varolanın adı ne olursa olsun, varolanlar her zaman Varlıkla/hakikatle ilişkide anlam bulurlar. Aynı zamanda varolanlar her zaman bir dünyanın açıklığıyla birlikte bulunurlar. Bu haliyle dünyanın hem içinde farklı ilişkilerin açığa çıktığı bağlam olduğu hem de, karşılıklı olarak, dünyanın bu ilişkilerde açığa çıktığı ileri sürülebilir. Dolayısıyla varolana verilen adların Varlığa, hakikate ve dünyaya dair ilişkileri ve değişmeleri anlamak için özel bir öneme sahip olduğu söylenebilir. 


\title{
On the Relationship Between Beings and the World on Heidegger
}

\begin{abstract}
Heidegger names beings differently in his texts. As names of beings change, their meanings change. Meanings of beings occur in their relationship with the world. Therefore, alongside beings, meaning of the world alters. But, despite this changes, like meanings of beings always occurring in their relationship with Being and world, there are similarities that are traceable.
\end{abstract}

\section{Keywords}

Fourfold, Art, Technical, Thing, Being. 


\section{KAYNAKÇA}

Altuğ, T. (2012) Son Bakışta Sanat, Yapı Kredi Yayınları, İstanbul.

Aşkın, Z. (2011) “Heidegger ve Adorno'nun Perspektifinden Teknik Kavramının Değerlendirilmesi”, ss, 41-55, Kaygı 17, Uludağ Üniversitesi Matbaası, Bursa.

Blitz, M. (2014) “Understanding Heidegger on Technology”, ss, 63-80, The New Atlantis No. 41, Center for the Study of Technology and Society.

Gadamer, H. G. (2010) “Sanat Yapıtının Doğruluğu”, çev. Metin Bal, ss, 131-146, Heidegger, Doğu Batı Yayınları, Ankara.

Gray, J. G. (2008) “Heidegger'in Yolu: İnsan Varoluşundan Doğaya”, çev. Ahmet Aydoğan, ss, 275-288, Heidegger, Say Yayınları, İstanbul.

Heidegger, M. (2002) “Dil”, çev. Hüsamettin Arslan, ss. 55-63, Insan Bilimlerine Prolegomena, Paradigma Yayınları, İstanbul.

-(2002) “Dilin Doğası”, çev. Hüsamettin Arslan, ss. 29-43, İnsan Bilimlerine Prolegomena, Paradigma Yayınları, İstanbul. Ankara.

-(1998) "Dönüş”, çev. Necati Aça, ss. 47-59, Teknik ve Dönüş, Bilim ve Sanat Yayınları,

-(2013) Hümanizm Üzerine, çev. Yusuf Örnek, Türkiye Felsefe Kurumu Yayınları, Ankara.

-(2008) “İnşa Etmek İskan Etmek Düşünmek”, çev. Ahmet Aydoğan, ss, 71-97, Düşüncenin Çă̆ırdı ̆̆ı, Say Yayınları, İstanbul.

-(2014) Metafiziğe Giriş, çev. Mesut Keskin, Avesta Yayınları, İstanbul.

-(1991) “Metafizik nedir?” çev. Yusuf Örnek, ss. 24-42, Metafizik Nedir?. Türkiye Felsefe Kurumu Yayınları, Ankara.

-(2012) “Metafiziğin Üstesinden Gelmek”, çev. Birdal Akar, ss. 187-204, Özne 16, Çizgi Kitabevi, Konya.

-(1997) “Metafiziğin Varlık-tanrı-bilimsel Yapısı”, çev. Necati Aça, ss. 29-62, Özdeşlik ve Ayrım, Bilim ve Sanat Yayınları, Ankara.

-(1997) “Özdeşlik İlkesi”, çev. Necati Aça, ss. 11-28, Özdeşlik ve Ayrım, Bilim ve Sanat Yayınlar1, Ankara. Şti, Ankara.

- (2011) Sanat Eserinin Kökeni, çev. Fatih Tepebaşıll, 2.Basım, De Ki Basım Yayım Ltd.

-(1991) “Sonsöz”, çev. Yusuf Örnek, ss. 43-52, Metafizik Nedir?. Türkiye Felsefe Kurumu Yayınları, Ankara.

-(2006) “Şey”, çev. Erdal Y1ldı,, Ali Kaftan, ss. 151-165, Kutadgubilig Felsefe-Bilim Araştırmaları Dergisi 9, Ana Basım Yayın, İstanbul.

-(2010) “Tanrılı̆̆ın Menşei”, çev. Kaan H. Ökten, ss. 8-15, Cogito 64 Heidegger: Varlı̆̆ın Çobanı, Yapı Kredi Yayınları, İstanbul. İstanbul.

-(1998) Tekniğe İlişkin Soruşturma, çev. Doğan Özlem, 2. Basım, Paradigma Yayınları,

-(2008) “Varlık ve Düşünme”, çev. Ahmet Aydoğan, ss, 19-40, Düşüncenin Çağırdiğl, Say Yayınları, İstanbul. 
-(2008) Varlık ve Zaman, çev. Kaan. H. Ökten, Agora Kitaplığı, İstanbul.

Kurtar, S. (2014) Heidegger ve Poetik Düşünme-Düşünmeye Açılan Yeni Yollar, Pharmakon Yayınevi, Ankara.

Nalbantoğlu, H. Ü. (1997) "Patikalar ve Otoyollar", ss, 173-229, Patikalar Martin Heidegger ve Modern Çağ, İmge Kitabevi, Ankara.

Özlem, D. (1998) "Giriş: Heidegger ve Teknik”, ss, 9-43, Tekniğe İlişkin Soruşturma, Paradigme Yayınları, İstanbul.

Quigley, T. R. (2008) "Sanat Eserinin Kökeni: Bir Hülasa", çev. Ahmet Aydoğan, ss, 321-329, Heidegger, Say Yayınları, İstanbul.

Sing, R. Raj (1990) "Heidegger and the World in an Artwork", ss, 215-222, The Journal of Aesthetics and Art Criticism Vol. 48, No. 3, Wiley on behalf of The American Society for Aesthetics. İstanbul.

Safranski, R. (2008) Bir Alman Üstat Heidegger, çev. Ali Nalbant, Kabalcı Yayınevi,

Sözer, Ö. (2010) "Giriş Heidegger Bağlamında Türkçeye Çevirmek-Türkçeyle Düşünmek", ss, 38-58, Heidegger, Doğu Batı Yayınları, Ankara.

Tepebaş1l1, F. (2011) “Heidegger’e Göre Sanat”, ss, 99-119, Sanat Eserinin Kökeni, 2.Basım, De Ki Basım Yayım Ltd. Şti, Ankara.

Zimmerman, M. E. (2010) "Heidegger'in Nietzsche Yorumunun Gelişimi”, ss. 258-280, Cogito 64 Heidegger: Varlığın Çobanı, Yapı Kredi Yayınları, İstanbul.

\section{KISALTMALAR}

DL: Dil

DD: Dilin Doğası

D: Dönüş

HÜ: Hümanizm Üzerine

İ: İnşa Etmek İskan Etmek Düşünmek

MG: Metafiziğe Giriş

MN: Metafizik nedir?

MÜ: Metafiziğin Üstesinden Gelmek

MV: Metafiziğin Varlık-tanrı-bilimsel Yapısı

Öİ: Özdeşlik İlkesi

SE: Sanat Eserinin Kökeni

S: Sonsöz

Ş: Şey

TíS: Tekniğe İlişkin Soruşturma

TM: Tanrılığın Menşei

VvD: Varlık ve Düşünme

VvZ: Varlık ve Zaman 